\title{
H1-9 wt Allele
}

National Cancer Institute

\section{Source}

National Cancer Institute. H1-9 wt Allele. NCI Thesaurus. Code C162868.

Human H1-9 wild-type allele is located in the vicinity of $17 q 21.33$ and is approximately 10 $\mathrm{kb}$ in length. This allele, which encodes spermatid-specific linker histone $\mathrm{H} 1$-like protein, plays a role in DNA accessibility during spermiogenesis. 